\title{
ANALISIS KEMAMPUAN PEMECAHAN MASALAH MATEMATIKA SISWA MENGGUNAKAN LANGKAH-LANGKAH POLYA DI TINJAU DARI ADVERSITY QUOTIENT TIPE CAMPERS DAN TIPE QUITTERS
}

\section{ANALYSIS OF STUDENTS' MATH PROBLEM-SOLVING SKILLS USING POLYA STEPS IN REVIEW OF ADVERSITY QUOTIENT TYPE CAMPERS AND QUITTERS TYPE}

\author{
Supriadi $^{a}$, Hidayani ${ }^{b}$, Irna Rusanic, Nika Fetria Trisnawati ${ }^{\mathrm{e}}$ \\ ${ }^{a}$ Program Studi Pendidikan Matematika FKIP Universitas Muhammadiyah Sorong \\ Jl. Pendidikan No. 23, KM 8, Sorong, Papua Barat, supriadiums@ gmail.com \\ ${ }^{\mathrm{b}}$ Program Studi Pendidikan Matematika FKIP Universitas Muhammadiyah Sorong \\ Jl. Pendidikan No. 23, KM 8, Sorong, Papua Barat, hidayani199319@gmail.com \\ c Program Studi Pendidikan Matematika FKIP Universitas Muhammadiyah Sorong \\ Jl. Pendidikan No. 23, KM 8, Sorong, Papua Barat, : irnarusani.ums@ gmail.com \\ ${ }^{\text {d }}$ Program Studi Pendidikan Matematika FKIP Universitas Muhammadiyah Sorong \\ Jl. Pendidikan No. 23, KM 8, Sorong, Papua Barat, nfetristrisnawati@ gmail.com
}

\begin{abstract}
ABSTRAK
Penelitian ini bertujuan untuk menganalisis kemampuan pemecahan masalah matematis siswa menggunakan langkah-langkah polya ditinjau dari Adversity Quotient (AQ) bertipe campers dan quitters. Penelitian ini merupakan penelitian kualitatif dengan jenis deskriptif. Subjek penelitian ditentukan melalui pemberian Angket AQ dan penelitian ini dilakukan di kelas X-A SMA Negeri 3 Kota Sorong dengan subjek berjumlah 4 siswa yang dibagi menjadi 2 kelompok. Kelompok pertama terdiri dari 2 siswa bertipe campers, dan kelompok kedua terdiri dari 2 siswa bertipe quitters. Teknik pengumpulan data pada penelitian ini menggunakan metode tes, metode wawancara tak terstruktur yang dilakukan kepada subjek yang telah terpilih dan metode dokumentasi. Teknik analisis data melalui reduksi data, penyajian data, dan penarikan kesimpulan. Hasil penelitian menunjukkan subjek dengan tipe campers pada soal yang di berikan cenderung dapat menentukan syarat cukup dan syarat perlu dalam memahami masalah, dapat menentukan keterkaitan syarat cukup dan syarat perlu dalam tahap menyusun rencana pemecahan masalah, dapat menyelesaikan masalah dengan langkah-langkah yang benar dan tepat, namun cenderung belum dapat menggunakan informasi yang sudah ada untuk memeriksa kembali jawaban yang di peroleh. Subjek dengan tipe quitter pada soal yang di berikan cenderung tidak dapat menentukan syarat cukup dan syarat perlu dalam memahami masalah, tidak dapat menentukan keterkaitan syarat cukup dan syarat perlu dalam tahap menyusun rencana pemecahan masalah, tidak dapat menyelesaikan masalah dengan langkah-langkah yang benar dan tepat, dan tidak dapat menggunakan informasi yang sudah ada untuk memeriksa kembali jawaban yang di peroleh.
\end{abstract}

\section{ABSTRACT}

The study aims to analyse students' mathematical problem-solving abilities using polya measures reviewed from adversity quotients (AQ) type campers and quitters. This research is qualitative research with descriptive types. The research subjects were determined through the provision of Angket AQ and this research was conducted in class X-A Sma Negeri 3 Kota Sorong with a subject of 4 students divided into 2 groups. The first group consists of 2 campers, and the second group consists of 2 students of the quitters type. The data collection technique in this study uses test methods, unstructured interview 
methods conducted to selected subjects and documentation methods. Data analysis techniques through data reduction, data presentation, and conclusion withdrawal. The results showed that subjects with campers types on the given problem tend to be able to determine sufficient conditions and necessary conditions in understanding the problem, can determine the linkage of sufficient terms and requirements needed in the stage of preparing a problem solving plan, can solve the problem with the right and appropriate steps, but tend not to be able to use existing information to re-examine the answers obtained. Subjects with the type of quitter on the given problem tend not to be able to determine sufficient conditions and conditions need to understand the problem, can not determine the linkage of sufficient terms and conditions needed in the stage of preparing a problem solving plan, unable to solve the problem with the right and appropriate steps, and can not use existing information to double-check the answers obtained.

Kata Kunci: pemecahan masalah matematika, Polya, Adversity Quotient, Campers, Quitters

\section{Pendahuluan}

Kemampuan yang harus dimiliki siswa dalam menyelesaikan masalah matematika berupa soal-soal atau tugas-tugas adalah kemampuan pemecahan masalah.

Kemampuan pemecahan masalah matematika siswa dapat di kategorikan menjadi tiga tingkatan yaitu tinggi, sedang, dan rendah. Siswa yang memiliki kemampuan pemecahan masalah matematika yang tinggi dapat menyelesaikan masalah berupa soal-soal atau tugas-tugas matematika secara menyeluruh ( Yanti \& Syazali, 2016).

Kemampuan pemecahan masalah matematika siswa dapat mengembangkan cara berpikir kritis, dan kreatif siswa (Isvina, Sugiarti, \& Kurniati, 2015; Kriel, 2013). Sehingga dapat dikatakan bahwa salah satu bagian penting pada pembelajaran matematika yaitu kemampuan pemecahan masalah, karna dengan kemampuan pemecahan masalah dapat melatih keterampilan maupun pengalaman pemecahan masalah matematika siswa sebagai pengetahuan yang sudah ada untuk menyelesaikan masalah matematika yang bersifat rutin maupun tidak rutin (Albert \& Kim, 2013). Selain itu, pengalaman pemecahan masalah dapat membantu dalam mengembangkan pengetahuan matematika dan mempromosikan kemampuan berpikir tingkat tinggi (Baraké, El-rouadi, \& Musharrafieh, 2015).

Pemberian permasalahan yang menantang dapat memunculkan kemampuan pemecahan matematika dan ini akan menumbuhkan cara berpikir kritis pada diri siswa (Kerkman \& Johnson, 2014). Pemecahan masalah matematika siswa sebagai proses aktivitas menyelesaikan masalah dari suatu kesulitan (Jihad, 2008). Salah satu alternatifnya untuk mempermudah siswa dalam memecahkan masalah, yaitu 
dengan menggunakan langkah-langkah Polya.

Terdapat empat langkah yang dapat digunakan dalam pemecahan masalah, yaitu 1) memahami masalah; 2) menyusun rencana penyelesain; 3) menyelesaikan masalah sesuai perencanaan, dan 4) memeriksa kembali hasil yang telah diperoleh (Polya, 1973). Langkah pertama memahami masalah, siswa dapat memahami masalah yang ada dengan cara mencari dan menentukan apa yang diketahui dan ditanyakan pada masalah. Langkah kedua menyusun rencana pemecahan masalah, siswa dapat menyusun rencana pemecahan masalah dari permasalahan yang ada berdasarkan yang diketahui dan ditanyakan pada tahap memahami masalah. Langkah ketiga melaksanakan rencana pemecahan masalah, siswa dapat melaksanakan rencana pemecahan masalah yang ada sesuai dengan pada tahap sebelumnya yaitu menyusun rencana pemecahan masalah dengan strategi yang telah dibuat, dan langkah keempat memeriksa kembali jawaban, siswa dapat memeriksa kembali jawaban yang telah diperolehnya, apakah jawabannya sudah benar atau sesuai dengan apa yang ditanyakan pada masalah atau belum.

Kemampuan pemecahan masalah matematika dapat di kelompokkan pada
Adversity Quotient (Stolts, 1997). Adversity Quotient merupakan kecerdasan seseorang dalam menghadapi rintangan atau kesulitan secara teratur (Stolts, 1997). Menurut Stolts (1997) AQ siswa dapat menjadi indikator untuk melihat seberapa kuatkah seseorang dapat terus bertahan dalam suatu masalah yang sedang dihadapinya. Selain itu juga, AQ dapat menjadi indikator untuk melihat bagaimanakah seseorang dapat mengatasi masalahnya, apakah mereka dapat menyelesaikan masalah yang dihadapi untuk menjadi pemenang ataukah menyerah bahkan berhenti ketika mengalami masalah yang di anggap sulit dihadapi. Stolts (1997) mengelompokkan AQ siswa dalam 3 kategori, yaitu: tipe quitter, camper, dan climber. Pertama siswa tipe Quitters adalah kelompok orang yang mudah menyerah, gampang larih dari masalah, menghindar dari masalah dan bahkan berhenti atau menyerah ketika mengalami masalah. Kedua siswa tipe Campers adalah kelompok orang yang memiliki kemauan menghadapi masalah akan tetapi mereka tetap tidak mengambil resiko terukur dan aman, sehingga menghentikan perjalanannya cukup sampai disini. Ketiga siswa tipe Climbers adalah kelompok orang yang memiliki keberanian dalam menghadapi masalah atau resiko sehingga pekerjaan mereka tuntas sesuai tujuannya. 
Septiana, Mardiyana, \& Sri (2014) menunjukan bahwa siswa dengan AQ tipe climbers, campers, dan quitters mempunyai prestasi belajar yang sama pada pembelajaran matematika. Wicaksana, Mardiyana, \& Usodo (2016) siswa tipe climbers mempunyai prestasi belajar matematika yang lebih baik dibandingkan siswa tipe campers dan quitters kemudian siswa tipe campers mempunyai prestasi belajar matematika yang sama dengan siswa tipe quitters. Sebaliknya pada penelitian Ain, Kusmayadi, \& Usodo (2017); siswa tipe climbers mempunyai prestasi belajar matematika yang sama dengan siswa tipe campers dan lebih baik dibandingkan siswa tipe quitters. Ardiyanto (2016) ; Ulfa (2016) siswa tipe climbers mempunyai prestasi belajar matematika yang lebih baik dibandingkan siswa tipe campers dan quitters kemudian siswa tipe campers mempunyai prestasi belajar matematika yang lebih baik dibandingkan siswa tipe quitters.

Permasalahan di atas menunjukkan bahwa dalam pemecahan masalah matematika terdapat rintangan-rintangan yang memerlukan tahap-tahap penyelesaian yang cukup panjang, sehingga tidak semua siswa dapat memecahkan masalah sesuai tahap-tahap penyelesaian, kecuali siswa yang memiliki ketahanan dalam menghadapi kesulitan. Selain permasalahan yang di munculkan di atas hasil survey yang dilakukan oleh TIMSS dan rata-rata ujian nasional tahun 2016 pada pembelajaran matematika juga masih rendah. Indonesia berada di urutan ke-38 dari 42 negara-negara dengan skor 386 dari rata-rata yang dipatok 500 point (Setiadi, Mahdiansyah, Rosnawati, Fahmi, \& Afiani, 2012) dan hasil ujian nasional tahun 2016 dengan rata-rata 58,61 (Puspendik, 2016).

Kemampuan pemecahan masalah matematika siswa Indonesia baik ditingkat Internasional maupun Nasional masi rendah jauh dari tujuan yang diharapkan, sehingga hal ini perlu ditingkatkan lagi untuk mencapai tujuan yang di inginkan. Kemampuan pemecahan masalah matematika dapat dipelajari, diajarkan, dan dapat pula di tingkatkan melalui proses pembelajaran (Ganesha, 2014; Gunantara, Suarjana, \& Riastini, 2014; Ikhsan \& Rizal, 2014). Proses pembelajaran akan bermakna jika siswa dapat memahami masalah sendiri, memecahkan masalahnya dan mempunyai kesempatan untuk menghadapi situasi realitas dalam kehidupan sehari-hari (Lee \& Sriraman, 2011). Salah satu upaya untuk menganalisis dan meningkatkan kemampuan pemecahan masalah matematika yang di tinjau dari AQ siswa tipe quitter, dan camper maka perlunya 
penggunaan langkah-langkah polya dalam penyelesain masalah matematika.

\section{Metode Penelitian}

Penelitian ini menggunakan penelitian kualitatif dengan jenis penelitian deskritif. Penelitian ini untuk menganalisis kemampuan pemecahan masalah matematika dengan menggunakan langkah-langkah Polya di tinjau dari AQ siswa tipe campers, dan quitters. Lokasi penelitian bertempat di SMA Negeri 3 Kota Sorong Tahun ajaran 2019/2020. Penelitian ini dilakukan pada tanggal 14 Agustus sampai dengan 18 September 2019. Subjek dalam penelitian ini adalah siswa kelas X IPA 1 SMA Negeri 3 Kota Sorong. Sedangkan cara pengambilan subjek dalam penelitian ini ditentukan melalui pemberian angket AQ. Hasil dari pemberian angket AQ dipilih sebagai subjek berjumlah empat siswa yang dibagi menjadi dua kelompok siswa tipe camper dan quitters.

Teknik pengambilan data pada penelitian ini menggunakan pemberian angket AQ siswa, tes terlulis, dan wawancara. Pengamatan dilakukan saat proses pembelajaran berlangsung di dalam kelas. Angket AQ digunakan untuk menentukan AQ siswa tipe camper dan quitters. Pemberian angket dilakukan sebanyak dua kali pertemuan, angket pertemuan kedua untuk lebih menyakinkan bahwa pengisian angket yang dilakukan siswa benar sesuai dengan AQ siswa tipe camper dan quitters. Kriteria yang digunakan untuk mengelompokkan tiga tipe AQ ini menggunakan kategorisasi berdasarkan model distribusi normal (Azwar, 2015). Penggolongan subjek ke dalam tiga kategori dapat dilihat pada tabel 3.1.

Tabel 1. Penggolongan Kriteria

Berdasarkan Mean Teoritik

\begin{tabular}{cl}
\hline Interval & Kriteria \\
\hline$X<(\mu-1,0 \sigma)$ & Quitters \\
$(\mu-1,0 \sigma) \leq X<(\mu+1,0 \sigma)$ & Campers \\
$(\mu+1,0 \sigma) \leq X$ & Climbers \\
\hline
\end{tabular}

Setelah dilakukan pengamatan, pemberian angket AQ, tes tertulis, dan Wawancara maka data di analisis. Data dianalisis menggunakan model Miles \& Hubermen, (2009) dengan dimulai dengan reduksi data, penyajian data dan penarikan kesimpulan. Reduksi data, Analisis hasil tes tertulis dan wawancara siswa menggunakan analisis kuantitatif yang bersifat deskriptif, untuk mendeskripsikan masing-masing variabel yang berdasarkan indikator langkah-langkah polya yaitu memahami masalah, melaksanakan rencana pemecahan masalah, menyusun rencana pemecahan masalah, dan memeriksa kembali jawaban, kemudian dijelasakan secara rinci dalam memecahkan masalah sistem persamaan linear tiga variabel (SPLTV). 


\section{Hasil dan Pembahasan}

Data hasil penelitian ini di peroleh dari hasil tes dan wawancara. Hasil tes dan wawancara di peroleh dari indikator kemampuan pemecahan masalah yang berdasarkan langka-langkag Polya yang meliputi, memahami masalah, membuat rencana pemecahan masalah, melaksanakan rencana pemecahan masalah, dan memeriksa kembali jawaban yaitu sebagai berikut :

\section{Memahami Masalah}

Tahap memahami masalah terlebih dahulu siswa membaca soal yang diberikan, siswa dapat menentukan syarat cukup (hal-hal yang diketahui) dan syarat perlu (hal-hal yang ditanyakan), siswa dapat menceritakan kembali masalah dengan bahasanya sendiri. Berikut ini hasil tes tulis dan wawancara siswa AQ tipe climber, tipe camper, dan tipe quitter pada tahap memahami masalah.

a) siswa AQ tipe camper.

Tahap memahami masalah siswa AQ tipe climber yang terpilih menjadi subjek penelitian ada dua yaitu subjek F-4 dan F-3. Kedua subjek dalam memahami masalah memiliki cara berpikir yang sama. Subjek F-4 dan F-3 cenderung dapat menentukan syarat cukup dan belum dapat menentukan syarat perlu, sebagaimana terlihat pada gambar :

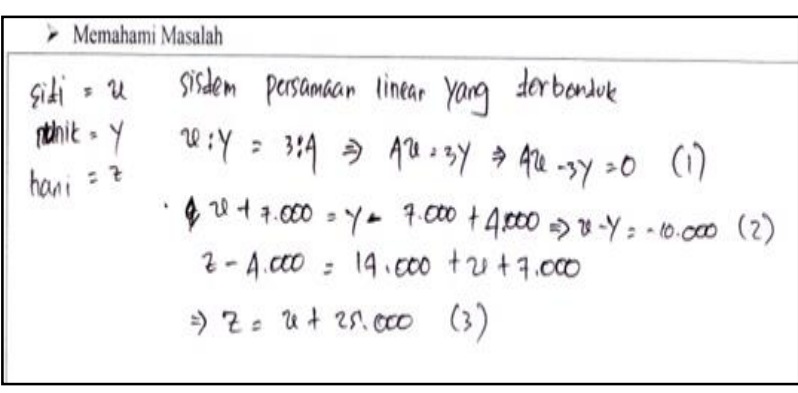

Gambar 1. Subjek F-4 Tahap Memahami Masalah

Subjek F-4 dalam memahami masalah pada soal kedua dapat menuliskan dengan kalimat matematika dengan memisalkan terlebih dahulu siti sama dengan $x$, nunik sama dengan $y$, dan hani sama dengan $z$. Selanjutnya subjek F-4 menuliskan sistem persamaan linear tiga variabelnya dalam model matematika yang dimana subjek F-4 menafsirkannya dari soal. Pertama, Perbandingan uang Siti dan Nunik adalah 3 : 4 dalam bentuk model matematikannya yaitu $x: y=3: 4$ dan di operasikan $4 x-3 y=0$ kemudian dimisalkan sebagai persamaan pertama. Kedua, Setelah Siti meminjam uang Rp. 7.000,00 kepada Nunik dan Nunik meminjam uang Rp. 4.000,00 kepada Hani, jumlah uang Siti sama dengan jumlah uang Nunik dalam bentuk model matematikanya yaitu $x+7.000=y-7.000+4.000$ dan di sederhanakan menjadi $x-y=-10.000$ kemudian dimisakan sebagai persamaan kedua. Ketiga, uang Hani masih Rp. 14.000,00 lebih dari jumlah uang Siti dalam 
bentuk model matematikanya yaitu $z-$ $4.000=14.000+x+7.000$ dan disederhanakan menjadi $z=x+25.000$ kemudian dimisalkan sebagai persamaan ketiga. Sehingga dapat dikatakan subjek F-4 sudah dapat menentukan syarat cukup dengan menuliskan apa diketahui dari masalah dan dapat menuliskan kembali masalah dengan bahasanya sendiri, namun siswa tidak dapat menuliskan apa yang di tanyakan pada syarat perlu. Namun pada saat dilakukan wawancara subjek F-4 mampu menyebutkan syarat cukup dan syarat perlu pada soal. Pada wawancara diatas subjek F-4 dapat menyebutkan syarat cukup dengan menuliskan apa diketahui dari masalah, dapat menyebutkan syarat perlu pada soal.

b) siswa $\mathrm{AQ}$ tipe quitter

Pada tahap memahami masalah siswa AQ tipe quitter yang terpilih menjadi subjek penelitian ada dua yaitu subjek F-2 dan F-1. Kedua subjek dalam memahami masalah cenderung memiliki cara berpikir yang sama. Subjek F-2 dan F-1 cenderung belum dapat menuliskan syarat cukup dan menentukan syarat perlu, namun pada saat dilakukan wawancara subjek F-1 mampu menyebutkan syarat cukup dan syarat perlu pada soal. Pada saat dilakukan wawancara subjek F-1 mampu menyebutkan syarat cukup dan syarat perlu pada soal, namun belum dapat menuliskan syarat cukup dan menentukan syarat perlu.

\section{Membuat Rencana Pemecahan Masalah}

Tahap membuat rencana pemecahan masalah siswa dapat mengetahui keterkaitan antara syarat cukup dan syarat perlu dan siswa dapat menggunakan semua informasi yang penting pada masalah untuk menentukan strategi apa yang sesuai dalam menyusun rencana penyelesain. Berikut ini hasil tes tulis dan wawancara siswa AQ tipe climber, tipe camper, dan tipe quitter pada tahap membuat rencana pemecahan masalah.
a) siswa AQ tipe camper
Pada tahap membuat rencana pemecahan masalah siswa AQ tipe camper yang terpilih menjadi subjek penelitian ada dua yaitu subjek F-4 dan F-3. Kedua subjek dalam memahami masalah memiliki cara berpikir yang sama. Pada permasalahan soal satu, dua, dan tiga subjek F-4 dan F-3 dalam menyusun rencana pemecahan masalah cenderung menggunakan strategi subtitusi dan gabungan eliminasi dan subtitusi. Berikut wawancara subjek F-3 dalam menyusun rencana penyelesain:
$P$ : Cara apa yang kamu gunakan untuk menyelesaikan masalah itu?
F-5 : Gabungan Elminasi Subtitusi 
$P$ : Selain cara Gabungan Elminasi Subtitusi, apakah ada cara lain untuk menyelesaikan masalah ini?

F-5 : cara subtitusi, eliminasi dan grafik pak.

Pada permasalahan soal nomor 2 dalam menyusun rencana penyelesain subjek F-3 dengan mengunakan strategi gabungan elminasi dan subtitusi, sebagaimana di tegaskan oleh subjek F-3 sebagai berikut:

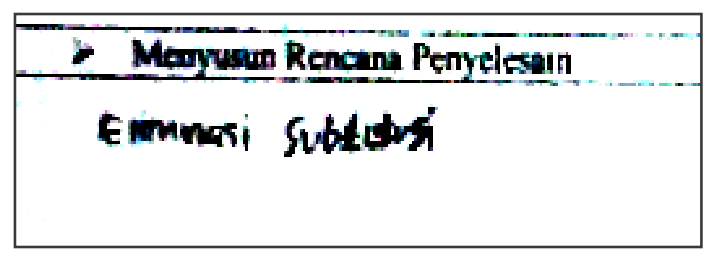

Gambar 2. Subjek F-3Membuat Rencana Pemecahan Masalah

Hasil di atas menegaskan bahwa subjek F-6 dalam menyusun rencana penyelesain mengunakan strategi gabungan elminasi subtitusi dan tampak percaya diri bahwa subjek F-6 lebih mudah menyelesaikan permasalahan dengan menggunakan strategi gabungan elminasi Subtitusi dari pada strategi lainnya.

b) siswa AQ tipe quitter

Pada tahap membuat rencana pemecahan masalah siswa AQ tipe camper yang terpilih menjadi subjek penelitian ada dua yaitu subjek F-2 dan F-1. Kedua subjek dalam membuat rencana pemecahan masalah memiliki cara berpikir yang sama. Pada permasalahan dua, dan tiga subjek F-2 dan F1 belum mampu membuat rencana pemecahan masalah. Hal ini di sebabkan pada tahap memahami masalah subjek F-2 dan F-1 tidak dapat menulis syarat cukup dan syarat perlu pada permasalahan.

\section{Melaksanakan Rencana Pemecahan Masalah}

Berdasarkan tahap sebelumnya yaitu membuat rencana pemecahan masalah siswa di harapkan dapat melaksanakan rencana pemecahan masalah sesuai dengan strategi yang direncanakan, mengerjakan dengan teliti, menggunakan langkah-langkah secara benar, terampil dalam algoritma dan ketepatan menjawab soal. Berikut ini hasil tes tulis dan wawancara siswa AQ tipe climber, tipe camper, dan tipe quitter pada tahap melaksanakan rencana pemecahan masalah.

a) Siswa AQ tipe camper
Pada tahap melaksanakan rencana pemecahan masalah siswa AQ tipe camper yang terpilih menjadi subjek penelitian ada dua yaitu subjek F-4 dan F-3. Kedua subjek dalam melaksanakan rencana pemecahan masalah memiliki cara berpikir yang sama. Pada permasalahan soal satu dan dua subjek F-4 dan F-3 dalam melaksanakan rencana pemecahan masalah siswa cenderung menggunakan strategi subtitusi dan gabungan 
subtitusi dan eliminasi. Berikut tampak contoh dalam melaksanakan rencana pemecahan masalah:

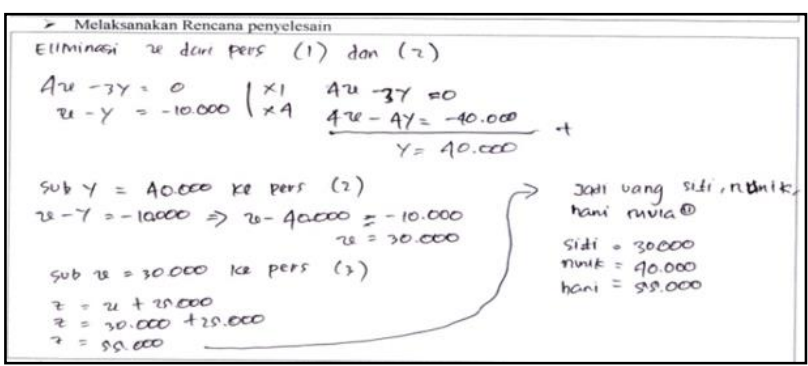

Gambar 3. Subjek F-3 Tahap Melaksanakan Rencana Pemecahan Masalah

Pada permasalahan ketiga diatas dalam menyusun rencana penyelesain subjek F-3 mengunakan strategi gabungan eliminasi dan subtitusi. Pertama subjek F-3 mengeliminasikan $x$ dari persamaan 1 dan persamaan 2 sehingga didapat $y=40.000$. kedua subjek F-3 mengsubtituskan $\mathrm{y}=$ 40.000 kepersamaan 2 sehingga didapat $\mathrm{x}=$ 30.000. ketiga subjek F-3 mengsubtitusikan $x=30.000$ ke persamaan 3 sehingga didapat $z=40.000 . \quad$ Tarakhir subjek F-3 menyimpulkan bahwa $x=30.000, y=$ 40.000 dan $z=55.000$. Pada proses penyenyelesain subjek F-3 tampak tidak ada kesalahan ataupun kesulitan dalam menyelesaikan permasalah soal nomor 2 . Pada saat wawancara menegaskan bahwa subjek F-3 dalam menyelesaikan rencana penyelesain mengunakan strategi gabungan eliminasi dan subtitusi dan tampak percaya diri bahwa subjek F-3 lebih mudah menyelesaikan permasalahan dengan menggunakan strategi gabungan eliminasi dan subtitusi dari pada strategi lainnya. Pada proses penyenyelesain subjek F-3 tampak tidak ada kesalahan ataupun kesulitan dalam menyelesaikan permasalah soal nomor 2 . Namun pada permasalahan ketiga subjek F-4 dan F-3 belum dapat melaksanakan rencana pemecahan masalah.

b) siswa AQ tipe quitter

Pada tahap melaksanakan rencana pemecahan masalah siswa AQ tipe camper yang terpilih menjadi subjek penelitian ada dua yaitu subjek F-2 dan F-1. Kedua subjek dalam melaksanakan rencana pemecahan masalah memiliki cara berpikir yang sama. Pada permasalahan dua, dan tiga subjek F-2 dan F-1 belum mampu melaksanakan rencana pemecahan masalah. Hal ini di sebabkan pada tahap memahami masalah subjek F-2 dan F-1 tidak dapat menulis syarat cukup dan syarat perlu pada permasalahan dan pada tahap membuat rencana pemecahan masalah siswa juga belum dapat menuliskan atau menentukan strategi pada permasalahan.

\section{Memeriksa Kembali Jawaban}

Tahap terakhir dalam memeriksa kembali jawaban siswa diharapkan dapat melakukan pemeriksaan hasil jawaban soal terhadap soal atau siswa dapat menggunakan informasi 
yang ada untuk mengerjakan kembali soal dengan cara yang berbeda. Berikut ini hasil tes dan wawancara pada subjek dari AQ tipe climber, AQ tipe campers, AQ tipe quitters pada tahap memeriksa kembali jawaban.

a) Siswa AQ tipe camper

Tahap memeriksa kembali jawaban siswa AQ tipe camper yang terpilih menjadi subjek penelitian ada dua yaitu subjek F-4 dan F-3. Kedua subjek dalam memeriksa kembali jawaban memiliki cara berpikir yang berbeda. Pada permasalahan soal satu, dan dua subjek F-4 dalam memeriksa jawaban pada permasalahan hanya membuktikan pada salah satu persamaan saja. Sedangkan subjek F-3 belum dapat menuliskan atau melakukan pemeriksaan ulang jawabannya. Berikut tampak contoh dalam memeriksa kembali jawaban pada permasalahan:

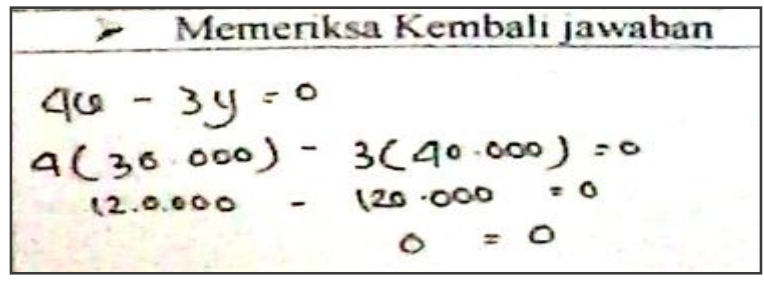

Gambar 4. Subjek F-4 Tahap Memeriksa Kembali Jawaban

Soal nomor dua subjek F-4 dalam memeriksa kembali jawaban dapat melakukan pemeriksaan ulang dengan subtitusikan subtitusikan nilai $x=$ 30.000 dan $y=120.000$, ke persamaan 1 .
Sehingga di hasilkan $0=0$, jika ruas kiri dan ruas kanan nilai sama maka terbukti jawabannya benar, Sebagaimana di tegaskan subjek F-4 sebagai berikut:

P Bagaimana cara kamu memeriksa jawabanmu ini benar?

$$
\begin{aligned}
& \text { F-4 subtitusikan nilai } x= \\
& 30.000 \text { dan } y=120.000, \quad k e \\
& \text { persamaan 1. Jadi di dapat sama } \\
& \text { antara ruas kiri sama dengan } 0 \text { dan } \\
& \text { ruas kanan } 0 \text { maka terbukti } \\
& \text { jawabanku benar. }
\end{aligned}
$$

Hasil wawancara di atas menegaskan bahwa subjek F-4 dalam memeriksa kembali jawaban tampak melakukan pemeriksaan ulang, namun dalam memeriksa kembali jawaban, subjek F-4 belum lebih rinci dalam melakukan pemeriksaan ulang, karna dalam hal membuktikan bahwa jawabannya benar yang telah dilakukan dengan cara membandingkan ruas kiri dan ruas kanan, seharusnya cara subtitusi nilai $x, y$, dan $z$ tidak hanya pada persamaan satu saja tapi juga pada persamaan dua dan tiga.

\section{b) Siswa AQ tipe quitter}

Pada tahap memeriksa kembali jawaban siswa AQ tipe camper yang terpilih menjadi subjek penelitian ada dua yaitu subjek F-2 dan F-1. Kedua subjek dalam memeriksa kembali jawaban memiliki cara berpikir yang sama. 
Pada permasalahan dua, dan tiga subjek F-2 dan F-1 belum mampu memeriksa kembali jawaban. Hal ini di sebabkan pada tahap memahami masalah subjek F-2 dan F-1 tidak dapat menulis syarat cukup dan syarat perlu pada permasalahan, pada tahap membuat rencana pemecahan masalah siswa juga belum dapat menuliskan atau menentukan strategi pada permasalahan dan pada tahap melaksanakan rencana pemecahan masalah siswa juga tampak memiliki kesulitan.

\section{Kesimpulan}

Berdasarkan rumusan masalah dan hasil analisis data dapat disimpulkan bahwa kemampuan pemecahan masalah matematika siswa kelas X IPA-1 SMA Negeri 3 Kota Sorong berdasarkan langkang-langkah Polya yang di tinjau dari AQ yaitu, Siswa tipe quitters pada tahap memahami masalah mampu dalam menyebutkan apa yang diketahui maupun di tanyakan pada saat wawancara, akan tetapi cenderung mengalami kesulitan pada saat menuliskan yang diketahui maupun yang ditanyakan dalam bentuk kalimat matematika. Tahap selanjutnya menyusun rencana pemecahan masalah dan melaksanakan rencana pemecahan masalah cenderung belum dapat menghubungkan yang deketahui maupun yang ditanyakan untuk menyusun strategi dan menyelesaikan masalah dengan benar dan tepat, dan belum dapat mampu memeriksa kembali jawaban.

Siswa tipe campers pada tahap memahami masalah mampu menuliskan dan menyebutkan yang diketahui serta menyebutkan apa yang ditanyakan pada saat wawancara, namun cenderung belum mampu dalam menuliskan yang ditanyakan dalam bentuk model matematika. Pada tahap menyusun rencana pemecahan masalah dan tahap melaksanakan rencana pemecahan masalah, cenderung mampu menghubungkan yang deketahui maupun yang ditanyakan untuk menyusun strategi dan menyelesaikan masalah dengan benar dan tepat. Tahap terakhir cenderung mengalami kesulitan dalam memeriksa kembali jawaban.

\section{Pustaka}

Ain, Q., Kusmayadi, T. A., \& Usodo, B. (2017). The Efectiveness of Numbered Heads Together With Guided Discovery Learning and Jigsaw Ii With Guided Discovery Learning Viewed From Adversity Quotient. The 1st Education and Language International Conference Procedings Center for International Language Development of Unissula, 655-664. 
Anggraini, L., Siroj, R. A., \& Putri, R. I. I. (2010). Penerapan Model Pembelajaran Investigasi Kelompok untuk Meningkatkan Kemampuan Pemecahan Masalah Matematika Siswa Kelas VIII-4 SMP Negeri 27 Palembang. Jurnal Pendidikan Matematika,4, 33-44.

Ardiyanto, D., Budiyono, \& Usodo, B. (2016). Eksperimentasi Model Pembelajaran Problem Based Learning (PBL), Team Assisted Individualization (TAI) Dan Student

Teams Achivement Divisions (STAD) Dengan Pendekatan Saintifik Terhadap Pemahaman Konsep Dan Ketrampilan Komputasi Matematika Ditinjau Dari Ad. Jurnal Elektronik Pembelajaran Matematika, 4(5), $510-524$.

Azwar, S. (2015). Penyusunan Skala Psikologi Edisi 2. Yogyakarta: Pustaka Pelajar.

Baraké, F., El-rouadi, N., \& Musharrafieh, J. (2015). Problem Solving at the Middle School Level: A Comparison of Different Strategies. Journal of Education and Learning, 4(3), $62-70$. http://doi.org/10.5539/jel.v4n3p62
Ganesha. (2014). Penerapan Model Pembelajaran Problem Based Learning untuk Meningkatkan Kemampuan Pemecahan. Mimbar PGSD Universitas Pendidikan Ganesha.

Gunantara, G., Suarjana, I. M., \& Riastini, P. N. (2014). Penerapan Model Pembelajaran Problem Based Learning untuk Meningkatkan Kemampuan Pemecahan Masalah Matematika Siswa Kelas V. MIMBAR PGSD, 2(1).

Isvina, W. Y., Sugiarti, T., \& Kurniati, D. (2015). Proses Berpikir Kreatif dalam Memecahkan Masalah Sub Pokok Bahasan Trapesium Berdasarkan Tahapan Wallas Ditinjau dari Adversity Quotient ( AQ ) Siswa Kelas VII-C SMP Negeri 1 Jember. Artikel Ilmiah Mahasiswa, 1(1), 1-7.

Kerkman, D. D., \& Johnson, A. T. (2014). Challenging Multiple-Choice Questions to Engage Critical Thinking. A Journal of Scholarly Teaching, 9, 92-97. Retrieved from http://search.ebscohost.com/login.as px?direct $=$ true $\& \mathrm{db}=$ eue $\& A N=1015$ $74386 \&$ site $=$ ehost-live Kriel, C. (2013). Creating a Disposition for 
Critical Thinking in The Mathematcs

Classroom. Proseding of the 2nd

Biennial Conference of the South

African Society for Enginering

Education, (Cape Town), 11-12 June 2013.

Lee, K. H., \& Sriraman, B. (2011). Conjecturing via reconceived classical analogy. Educational Studies in Mathematics, 76(2), 123 140.

Polya, G. (1973). To Solve It (A New Aspect of Mathematical Method). New Jersey: Priceton University Press.

Puspendik. (2016). Laporan Hasil Ujian Nasional Tahun Pelajaran 2015/2016. BalitbangKemendiknas.

Rosita, D., \& Rochmad. (2016). Analisis Kesalahan Siswa Dalam Pemecahan Masalah Ditinjau Dari Adversity Quotient Pada Pembelajaran Creative Problem Solving. Unnes Journal of Mathematics Education Research (UJMER), 5(2), 106-113. Retrieved from http://journal.unnes.ac.id/sju/index. php/ujmer

Santos, M. C. J. (2012). Assessing the effectiveness of the adapted adversity quotient program in a special education school. International Refereed Research Journal, 3(4), 13-24.

Sari, C. K., Sutopo, \& Aryuna, D. R. (2016). The Profile o f Students ' Thinking in Solving Mathematics Problems Based on Adversity Quotient. Journal of Research and Advances in Mathematics Education, 1(1), 3648.

Septiana, W., Mardiyana, \& Sri, S. (2014). Eksperimentasi Model Pembelajaran Kooperatif Tipe Teams Games Tournament Dengan Pendekatan Realistic Mathematics Education Pada Materi Pokok Persamaan Dan Pertidaksamaan Linier Satu Variabel Ditinjau Dari Adversity Quotient Siswa Kelas VII SMP Negeri Se-K. Jurnal Elektronik Pembelajaran Matematika, 2(3), 291-300.

Setiadi, H., Mahdiansyah, Rosnawati, R., Fahmi, \& Afiani, E. (2012). Kemampuan Matematika Siswa SMP Indonesia: Menurut Benchmart Internasional TIMSS 2011. Jakarta (Vol. 13). Pusat Penilain Pendidikan Badan Penelitian Dan Pengembangan Kementrian Pendidikan dan Kebudayaan. 
Stolts, P. G. (1997). Adversity Qoutient: turning obstacles into opportunities, 1997.

Ulfa, N. F., Kusmayadi, T. A., \& Sujadi, I. (2016). Eksperimentasi Model Pembelajaran Kooperatif Tipe Team Assisted Individualization (TAI) Dan Think Talk Write (TTW) Pada Materi Fungsi Ditinjau Dari Adversity Quotient Siswa Kelas VIII SMP Negeri Se-Kabupaten Boyolali Tahun Pelajaran 2015/2016. Jurnal Elektronik Pembelajaran Matematika, 4(10), 898-911.

Ventakesh, J., Shivaranjini, G., Thenmozhi, S., Balasubramanie, P., \& Gandhi, S. M. (2014). Adversity quotient and resilient HR culture: A success strategy for organizations. International Journal of Scientific Research and Management (IJSRM), 2(8), 1236-1240.

Wicaksana, H., Mardiyana, \& Usodo, B. (2016). Eksperimentasi Model Pembelajaran Problem Based Learning (PBL) Dan Discovery Learning (DL) Dengan Pendekatan Saintifik Pada Materi Himpunan Ditinjau Dari Adversity Quotient (AQ) Siswa. Jurnal Elektronik Pembelajaran Matematika, 4(3),
258-269.

Yani, M., Ikhsan, M., \& Marwan. (2016). Proses Berpikir Siswa Sekolah Menengah Pertama Dalam Memecahkan Masalah Matematika Berdasarkan Langkah-Langkah Polya Ditinjau dari Adversity Quotient. Jurnal Pendidikan Matematika, 10(1), 42-48.

Yanti, A. P., \& Syazali, M. (2016). Analisis

Proses Berpikir Siswa Dalam Memecahkan Masalah Matematika Berdasarkan Langkah-Langkah Bransford Dan Stein Ditinjau Dari Adversity Quotientsiswa Kelas X Man 1 Bandar Lampung Tahun. AlJabar, 7(1), 108-122. 